\title{
HAMMER MILL LOAD CURRENT ADAPTIVE CONTROL SYSTEM TRIALS
}

\author{
Khobin V.A., Levinskyi V.M., Levinskyi M.V. \\ Odessa National Academy of food technologies, Odessa \\ ORCID: 0000-0002-6544-5110 \\ E-mail: MaxLevinskyi@gmail.com
}

Copyright (C) 2018 by author and the journal “Automation technologies and business - processes. This work is licensed under the Creative Commons Attribution International License (CC BY). http://creativecommons.org/licanses/by/4.0

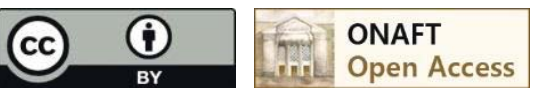

\section{DOI: 10.15673/atbp.v10i1.874}

\begin{abstract}
Анотація: Прочес дроблення компонентів комбікормів досить енерговитратний, причому залежність питомоі витрати енергії від продуктивності молоткової дробарки носить екстремальний характер $i$ мінімум изього екстремуму дрейфує при зміні складу і властивостей сировини. Однак використання пошукових екстремальних систем керування стримується через те, щзо системи автоматичного регулювання струму навантаження електропривода дробарки на практиці часто стають нестійкими. Для даного об'єкта регулювання доцільно використати систему з самоналагодженням параметрів регулятора. Властивості дробарки як об'єкта регулювання добре підходять для перевірки ефективності алгоритмів даної системи, оскільки, по-перше, коефіцієнт передачі по каналу керування змінюється більи ніж в десять раз, по-друге, вона має суттєво нелінійну статичну характеристику, відрізняється невизначеністю параметрів моделей динаміки. В роботі порівнюється функціонування системи автоматичного регулювання з постійними налаштуваннями регулятора $i$ системи із самоналагодженням. Результати імітаційного $i$ напівнатурного моделювання підтвердили ефективність розроблених алгоритмів самоналагодження та коректність їх програмної реалізації. Система стійко функиіонує у всьому робочому діапазоні навантажень, отже вона може бути використана в складі систем оптимізації як адаптивна система стабілізаиіï.
\end{abstract}

Abstract: Mixed fodder components milling process is quite energy-consuming. Dependence of specific energy consumption on the hammer mill productivity is extremal and the minimum of this extremum drifts with changing composition and qualities of the raw materials. Extremum search control systems utilization, however, is constrained due to the fact that automatic control systems (ACS) of the hammer mill drive electric motor (DEM) current load, as practice shows, often become unstable. For this control object (CO) it is practical to use ACS with self-tuning of the controller parameters. Hammer mill properties as a CO are well suited for verifying the efficiency of the algorithms of this system, because, firstly, the control channel transition coefficient changes in ten or more times, secondly, it has substantially nonlinear static characteristic and has the uncertainty of the parameters of the dynamic models. Functioning of the ACS with constant parameters of the controller and self-tuning ACS (STACS) are compared in this research. Results of the simulation and semi-industrial trials confirmed the developed self-tuning algorithms effectiveness and verified their software implementation. The system operates steadily throughout operating range of loads, therefore, it can be used as a part of optimization systems as an adaptive system of stabilization.

Ключові слова: система автоматичного регулювання із самоналагодженням, математична модель молоткової дробарки, імітаційне та напівнатурне моделювання.

Keywords: self-tuning automatic control system, hammer mill mathematical model, simulation, semi-industrial trials.

\section{Introduction}

Hammer mills effective control is a topical issue, given that the milling the components of mixed fodder process is quite energy-consuming and, therefore, the power of DEM is significant: for some models it reaches $600 \mathrm{~kW}$ [1]. Dependence of specific energy consumption on the hammer mill productivity is extremal and the minimum of this extremum drifts with changing composition and qualities of the raw materials [2, 3]. Extremum search control systems utilization, howerver, is constrained due to the fact that ACS of the hammer mill DEM current load $I$ become unstable with increasing set points $I^{z}$, because hammer mill static characteristic, as a CO, through channel «control impact $u$ raw material feeding rate - DEM current $I$ load» is non-linear. Consequently, when the control signal $u$ changes, CO gain $k_{o}$ changes as well [2, 3]. Significant $k_{o}$ 
increase is usually observed in the transition from the optimal mode of energy consumption to the mode of maximum hammer mill productivity, when the time of production performance becomes the main indicator of efficiency. Constant manual retuning of the current load stabilization system is quite complicated, operator errors can not be ruled out; therefore for this CO it is expedient to use STACS to the CO gain that varies.

\section{Analysis of literary data and problem statement}

Hammer mills mathematical models as CO are presented in [2, 3]. These models were obtained using different approaches. Their structure was determined on the basis of physical processes in the hammer mill components: feeder, milling zone, DEM. And the parameters were obtained through experiments. Simulation models which were developed for the MatLab/Simulink environment take into account stochastic nature of the uneven flow of raw materials, fluctuations of the supply voltage, backlashes in the actuators and other specific features of the hammer mill operation.

Static characteristics of the hammer mill, which were obtained during simulation [3], are presented on fig. 1.

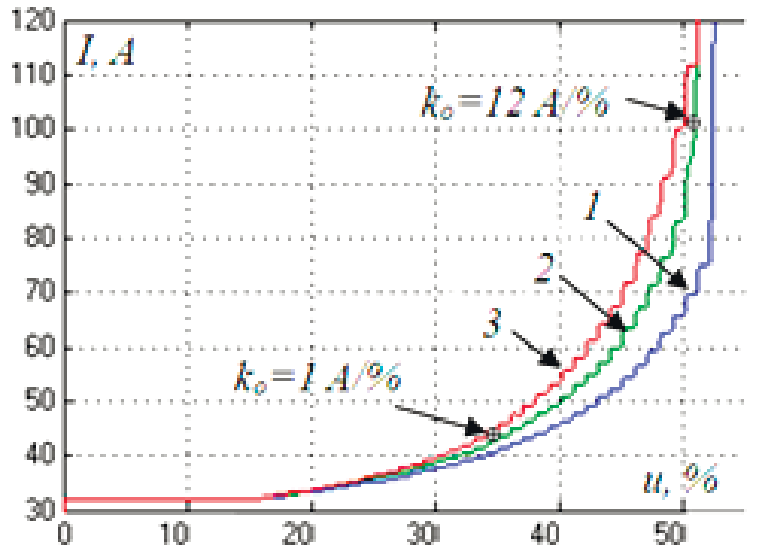

a)

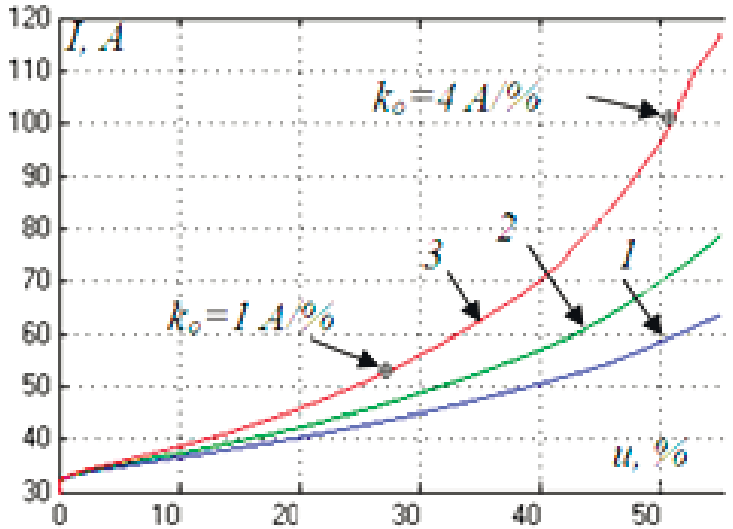

b)

a) hammer mill with gate valve; b) with rotary valve feeder during milling:

1- maize; 2 - wheat; 3 - barley

Fig. 1 - Static (quasi-static) characteristics of the hammer mill

Analyzing these characteristics, we can conclude that they are non-linear and, depending on the current values of the control influence $u$, the gain $k_{o}$ of the hammer mill as a CO changes widely from 1 to $12 \mathrm{~A} / \%$. Obviously, in such conditions, the ACS with constant controller parameters with changing of the set point $I^{z}$, and, consequently, values of $u$, may become unstable.

Using the models in [3], dynamic characteristics of the hammer mill as a CO were obtained utilizing the active experiment method for two ranges of control influence changes. The results are presented in fig. 2.

The analysis of the transient processes shows that the time delay of the CO model practically does not depend on the type of raw material and the control impact rage change. But the response time $T_{o}$ of the models increase in 1,5-2 times with control impact increase and depend on the type of raw material. These experiments show the hammer mill dynamic characteristics uncertainty. This additionally complicates ACS implementation with constant controller parameters and emphasizes the necessity to implement adaptive control systems with self-tuning of the controller parameters.

Such STACS is described in detail in [4], but in this system as a CO control channel model was used one in a form of linear differential equation with changing parameters, of which CO gain changing the most. Such simplified models are traditionally used at the stage of theoretical studies, because they allow to trace the cause and effect connections between variables or parameters which are important for a particular problem. At the same time such "formal" models have significant drawbacks they don't reflect many of the properties of real CO concerning which self-tuning algorithms may turn out to be non-robust.

Taking into account the abovementioned specifics of the hammer mill mathematical models, it can be concluded that it is expedient to use it as a test object to verify the effectiveness of the STACS. 

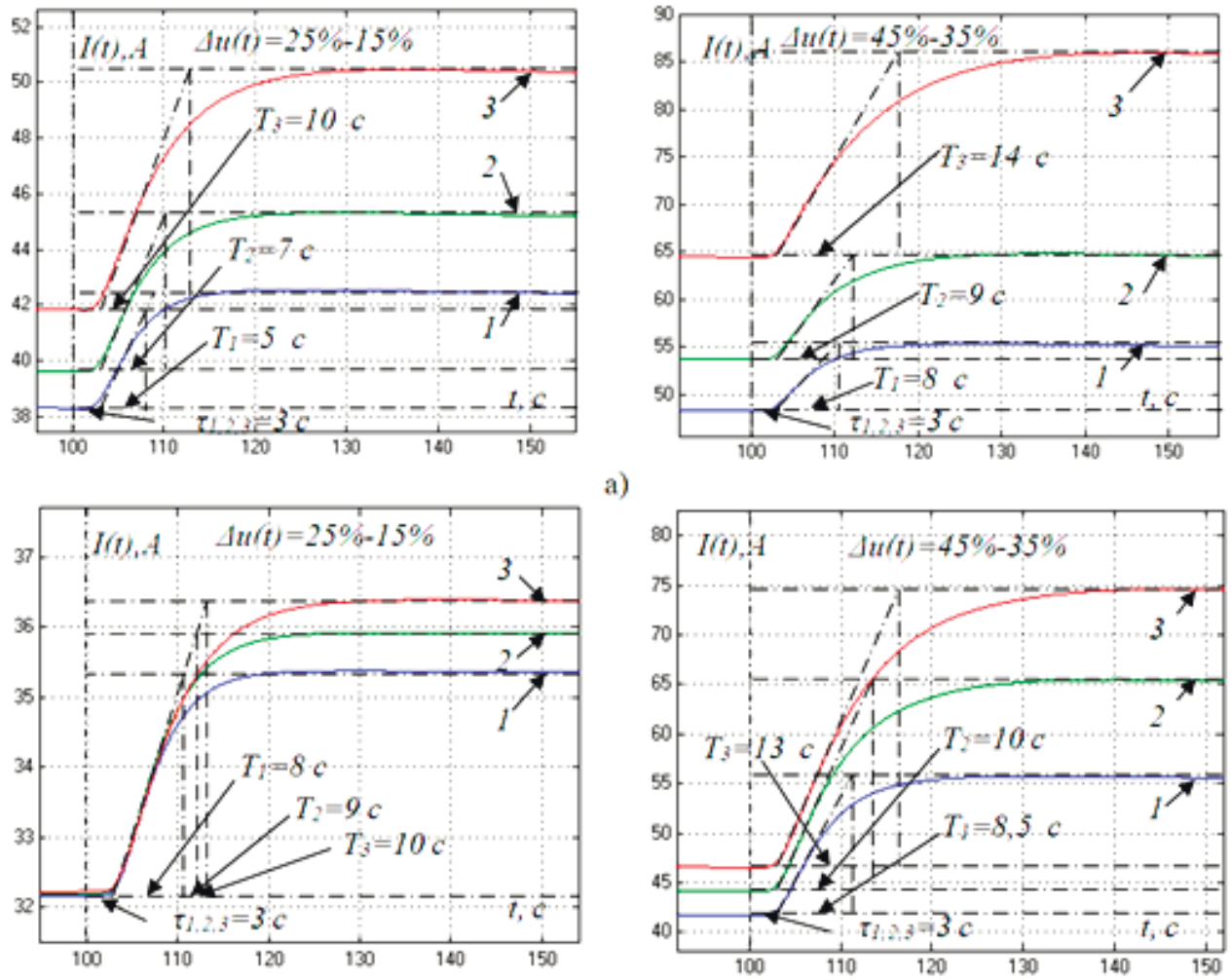

b)

Dynamic characteristics of the hammer mill model with rotary valve feeder (a) and with gate valve (b) during milling:

1 - maize; 2 - wheat; 3 - barley with step change in control influence $\Delta u(t)=10 \%$ from different ranges

Fig. 2 - Demonstration of the hammer mill dynamic characteristics uncertainty

\section{Goal and tasks of the research}

Goal is to verify the effectiveness of the STACS functioning with a test object. The gain in such object changes in a wide range, parameters of the dynamic characteristics are not precisely defined and its model includes nonlinearities that are typical for many real technological objects. The tasks include: a) to carry out research of ACS with constant controller parameters during stabilizing of hammer mill DEM load current in the conditions of the uncontrollable external disturbances impact and with changing set point value; b) to conduct research of STACS functioning in the same experimental conditions.

\section{Methods and materials of the research}

Since STACS model includes non-linear and non-stationary dynamic links, it is impossible to solve the problem analytically. Therefore, simulation and semi-industrial trials, conducted using MatLab/Simulink environment, were chosen as methods of research. During semi-industrial trials functional block which implements STACS self-tuning algorithms which were developed during simulation, is loaded and executed in an industrial controller. CO stays in the form of a simulation model and functions in the Simulink environment. This allows to carry out verification of the self-tuning program module, to identify possible errors and specifics associated with the transition to a digital form of algorithms implementation (the effects of quantization in time and magnitude, the instability of computational procedures, etc.)

Specifics of semi-industrial trials: a) it is conducted in real time; b) the "virtual" model of the CO compared to the real plant significantly reduces the cost of conduction experiments and allows one to understand the functioning of the system in different modes, including those close to the emergency situation.

\section{Research results}

In conditions of uncertainty two variants of ACS with constant controller parameters synthesis are possible: the first one to conduct it for worst CO parameters combination; the second one - for conditionally averaged CO parameters.

Transient characteristics presented in fig. 2 allowed to accept the worst combination of CO parameters numerical values: $k_{o}=12 \mathrm{~A} / \%, \tau_{o}=3 \mathrm{~s}$ and $T_{o}=5 \mathrm{~s}$; conditionally averaged numerical values of CO model parameters: $k_{o}=1 \mathrm{~A} / \%, \tau_{o}=3 \mathrm{~s}$ and $T_{o}=10 \mathrm{~s}$. Utilizing the engineering method [5] ACS PI controller parameters were calculated. For the first option: gain $k_{r}=0,13 \% / A$ and integral action time $T_{i z}=9,6 \mathrm{c}$; for the second option: gain $k_{r}=3,7 \% / \mathrm{A}$ and integral action time $T_{i z}=6$ c. During simulation aperiodic set point formation link was used in the ACS structure and uneven flow of raw materials was simulated as well. This led to its reflection on DEM load current changing characteristics. 
The simulation results showed that in the case of using the worst combination of CO parameters during ACS synthesis, it remained operational (stable) throughout the operating range of $I^{z}(t)=35 \ldots 55$ A changes (see fig. 3). However, because of the small controller gain value $k_{r}$ there is low dynamic accuracy of the stabilization (up to $\pm 10 \mathrm{~A}$ ). This is due to poor suppression of external coordinate disturbances. This, in its turn, can trigger the hammer mill DEM thermal protection circuit.

When simulating search movements of the optimization system, which changed the set point value $I^{z}(t)$ of the stabilization system, for example, according to harmonic law, hammer mill DEM current load ACS does not provide sufficient accuracy of the $I^{z}(t)$ tracking.

When utilizing conditionally averaged CO parameters in the ACS synthesis, then the system is operational (stable) but only for a certain value of DEM load current, e.g. $I^{2}=35$ A. However, with the current value increase to $I^{2}=55$ A, the system becomes unstable (see fig. 1). This is a consequence of non-linear static characteristic of the hammer mill models.

When simulating searching moves of the optimization system, the ACS with rotary valve feeder turned out to be nonoperational. And this fact impedes the implementation of the optimization systems for hammer mills.

STACS simulation for hammer mill model in MatLab/Simulink environment was carried out for similar conditions (see fig. 5.). As it follows from its results, in contrast to the conventional ACS, STACS is stable in all operating range of loads $I^{z}(t)=35 \ldots 55$ A. Since the static characteristic of the hammer mill is non-linear, the controller influence does not exceed its limit value of $100 \%$. When simulating search moves of the optimization system, developed STACS provides tracking for changing set point value of $I^{2}(t)$ with sufficient for practical applications accuracy.

The results of semi-industrial trials of STACS with self-tuning algorithms implemented in industrial controller, and the hammer mill model in Simulink using Real-Time Windows Target library [6], are presented in fig. 6. Analysis of the trends shows, that developed self-tuning algorithms are effective for such $\mathrm{CO}$ as hammer mill and also their software implementation is verified. STACS is stable in all operating loads range $I^{z}(t)=35 \ldots 55$ A and provide tracking for changing set point value according to harmonic law $I^{z}(t)$. Consequently, it can be used as adaptive subsystem of stabilization in search optimization system.
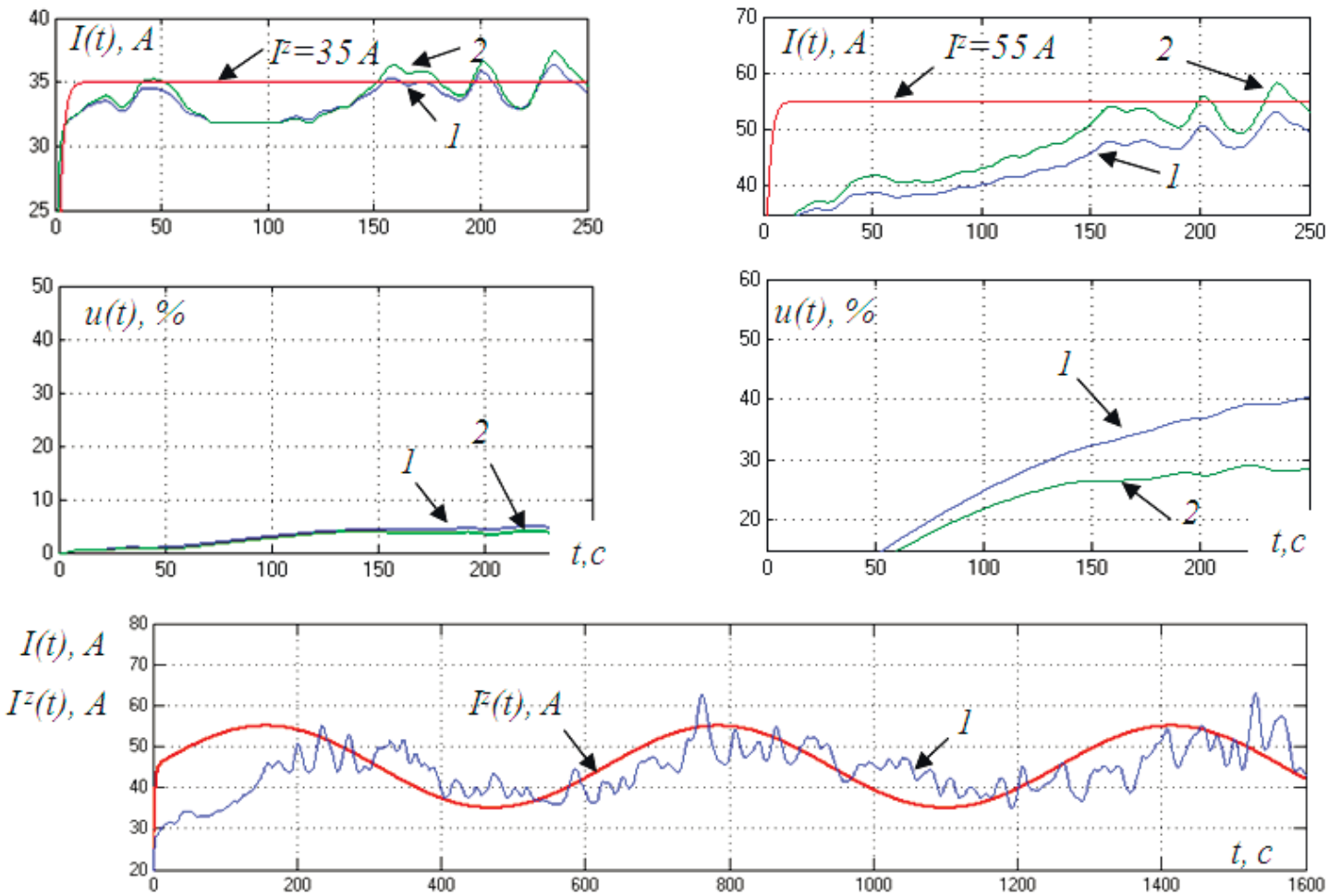

Hammer mill with rotary valve feeder (CO model with worst parameters) during milling of: 1 - maize; 2 - barley

Fig. 3 - ACS operation with constant controller parameters in modes: startup and stabilization; simulation of extremum search 

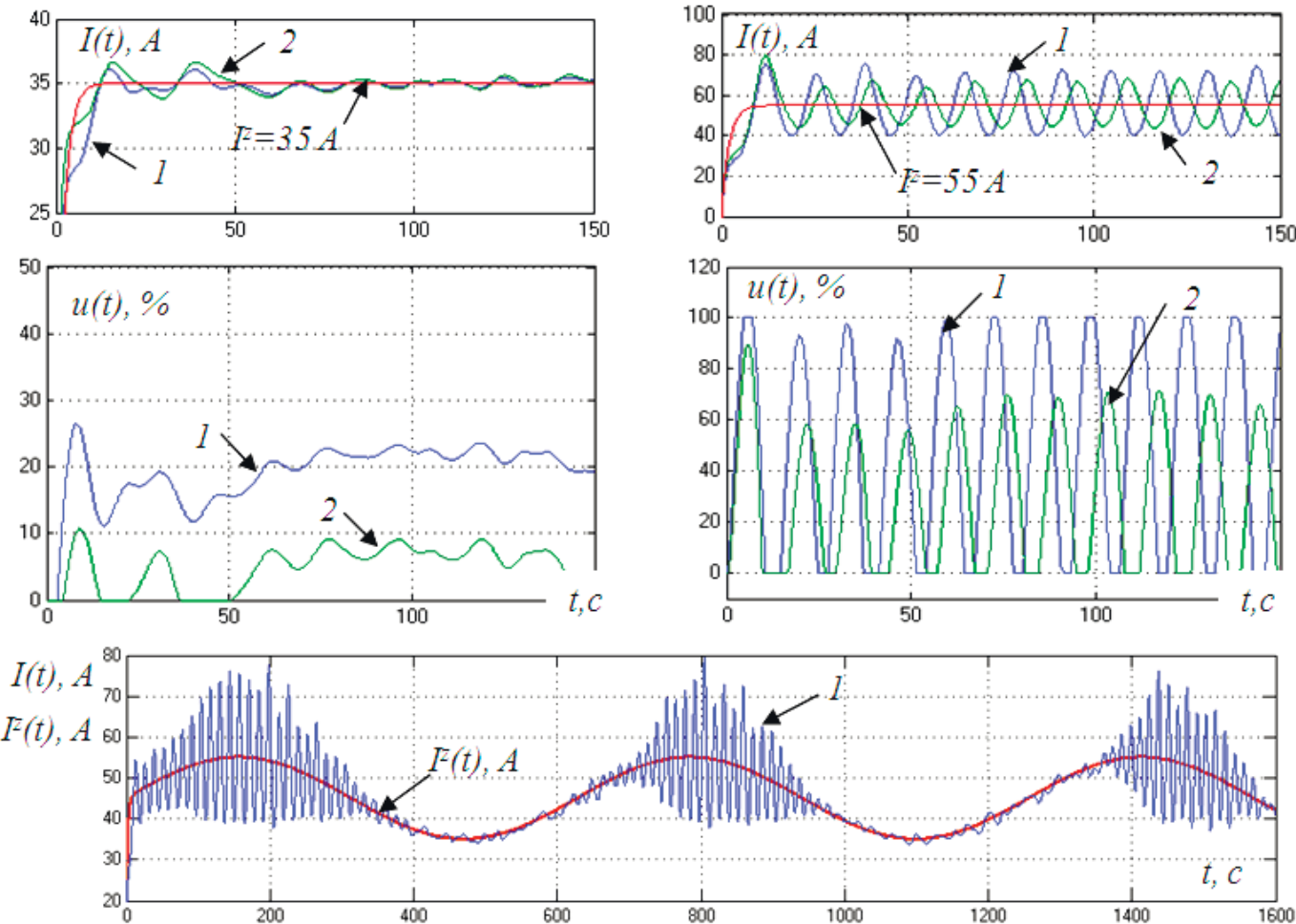

Hammer mill with rotary valve feeder (CO model with conditionally averaged parameters) during milling of: 1 - maize; 2 - barley

Fig. 4 - ACS operation with constant controller parameters in modes: startup and stabilization; simulation of extremum search
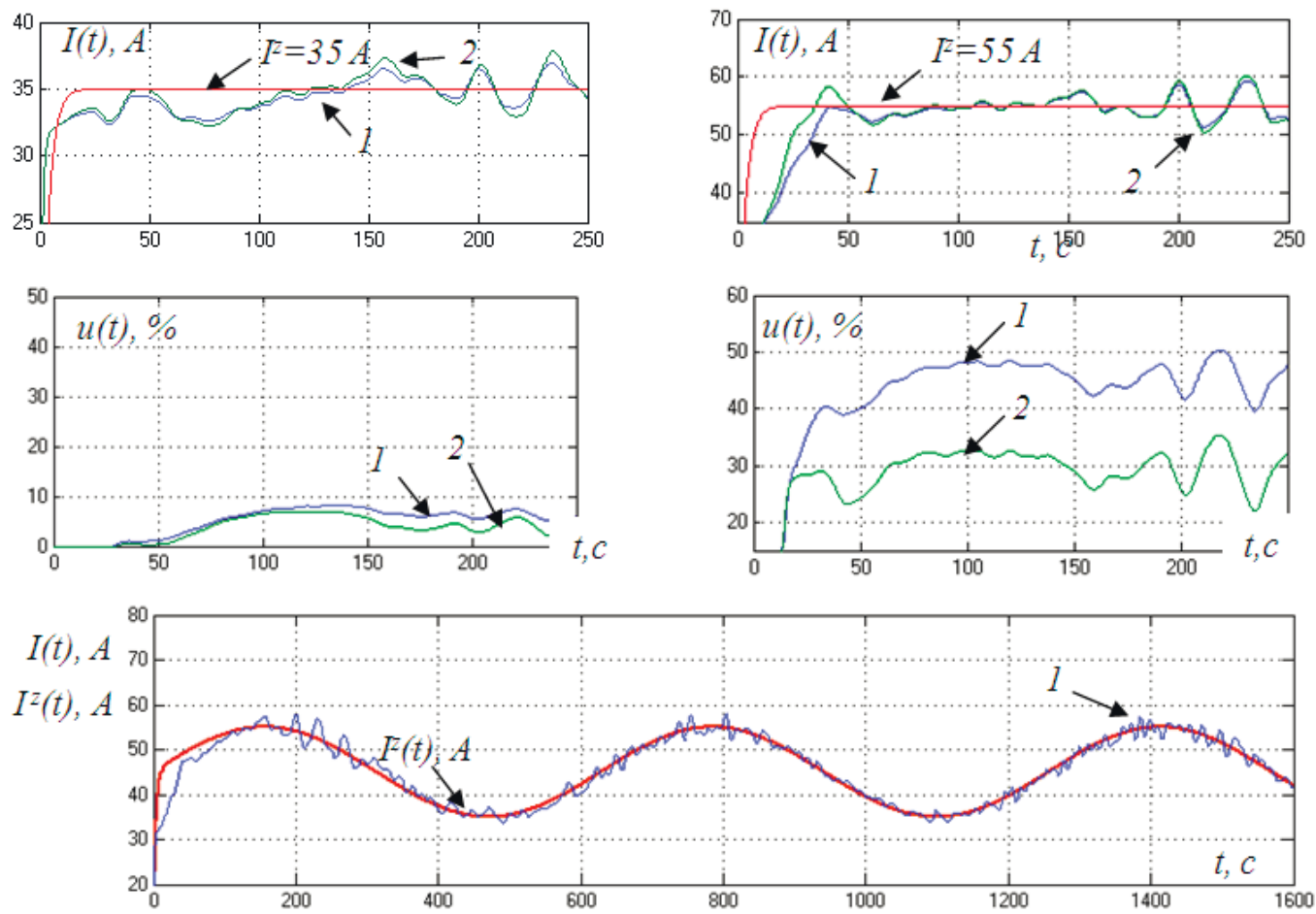

Hammer mill with rotary valve feeder (CO model with conditionally averaged parameters) during milling of: 1 - maize; 2 - barley

Fig. 5 - STACS operation in modes: startup and stabilization; simulation of extremum search 


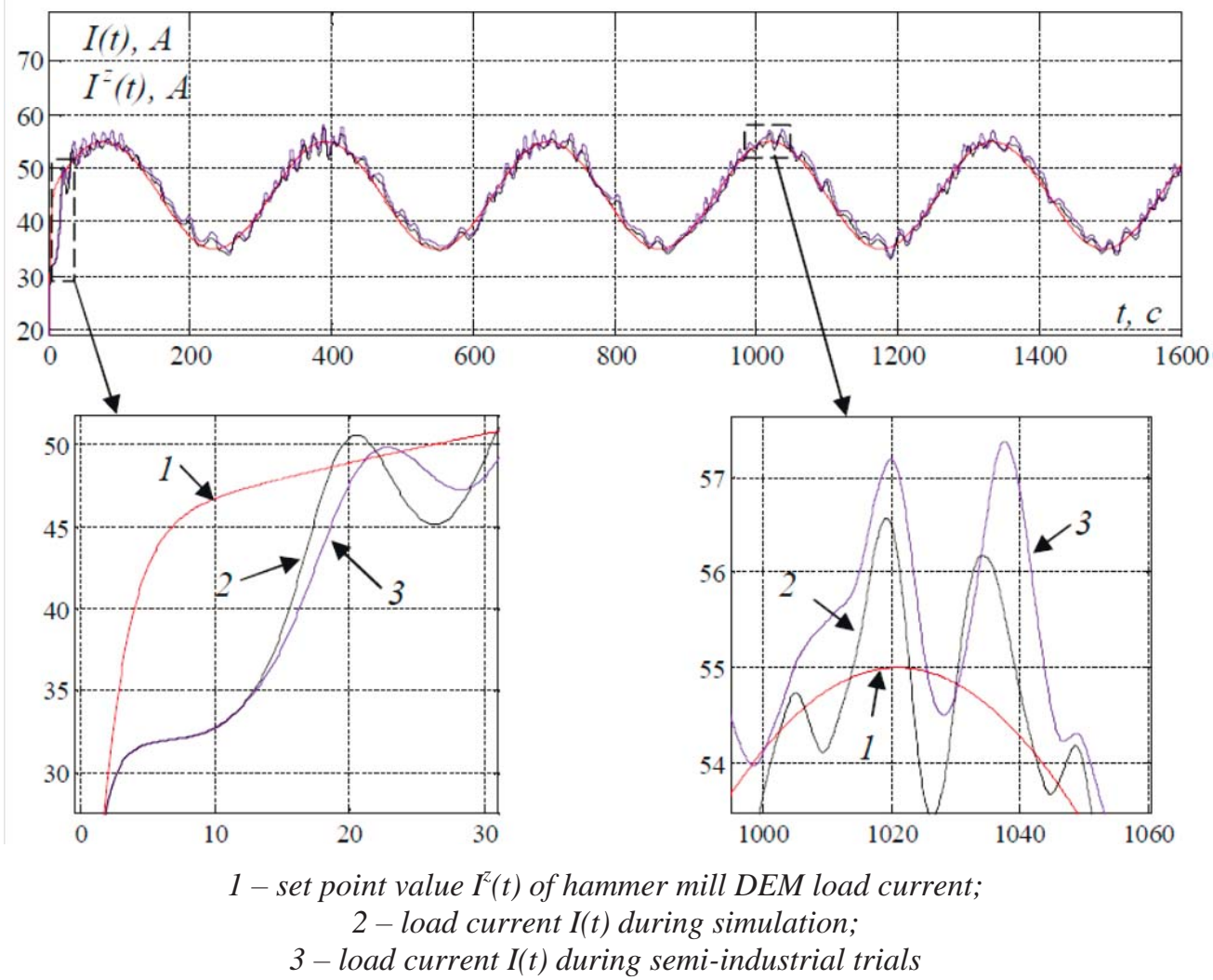

Fig. 6 - Comparing the results of STACS simulation and semi-industrial trials

\section{Discussion of the results}

The results which were obtained during STACS research with the hammer mill as a CO, further confirms the legitimacy of the controller self-tuning in the closed-loop ACS concept, utilizing passive identification of the CO and separating own motion of the closed-loop ACS from the total motion component. It should be noted that even in conditions when adopted hypothesis in [4] about low-frequency nature of the CO gain change is violated, since for hammer mill it changes very quickly, STACS still ensures the fulfillment of its functions.

\section{Conclusions}

1. Choosing the hammer mill as a CO to verify the effectiveness of the developed self-tuning algorithms is justified. Properties of the hammer mill are adequate to the task, since its gain through the control channel changes in 10 or more times, secondly it has substantially non-linear static characteristic, including nonlinearity of the "backlash" and "dead band zone" types, as well as dynamic nonlinearity of "actuator with constant speed" type. The listed specifics reflect the properties of not only hammer mills, but also many other real plants.

2. Computer experiments with simulation models of hammer mill ACS for different kinds of raw materials revealed the following: a) ACS with constant controller parameters, which were calculated for worst combination of CO parameters, does not provide sufficient dynamic accuracy and with conditionally averaged parameters of the CO, does not provide stability, in particular, with increase in raw materials feed rate; b) developed STACS ensures the stable operation of the hammer mill in the entire working loads range, in particular, when tracking the variable set point value of the DEM load current. This makes it possible to apply STACS as a part of the optimization system as an adaptive stabilization system.

3. Semi-industrial trials of STACS showed that the software implementation of the developed self-tuning algorithms was done correctly, since the results of semi-industrial trials almost coincide with the results obtained during simulation in Simulink. When controlling the hammer mill model which is calculated on a PC in real time, the stable operation of the STACS throughout the whole working range of loads is observed.

\section{References}

[1] Afanasyev, V. (2007). Rukovodstvo po tehnologii kombikormovoj produkcii s osnovami kormleniya zhivotnyh. 1st ed. Voronezh: Vserossijskij nauchno-issledovatelskij institut kombikormovoj promyshlennosti, pp.1-389.

[2] V. Khobin and A. Babikov, "Matematicheskaya model rabochej zony sitovoj molotkovoj drobilki kak obekta upravleniya s izmenyayushimisya svojstvami", Naukovi praci ONAHT, vol. 2, no. 30, pp. 304-310, 2007.

[3] V. Khobin and A. Babikov, "Matematicheskaya imitacionnaya model molotkovoj drobilki kak obekta upravleniya v srede Simulink", Naukovi praci ONAHT, vol. 2, no. 29, pp. 236-240, 2006.

[4] V. Khobin and M. Levinskyi, "Optimizaciya filtrov sobstvennogo dvizheniya samonastraivayushejsya SAU obektom 
tehnologicheskogo tipa", Radioelektronika, informatika, upravlinnya, no. 4, pp. 120-129, 2016.

[5] A. Kopelovich, Inzhenernye metody raschyota pri vybore avtomaticheskih regulyatorov, 1st ed. Moskva: Metalurgizdat, 1960, pp. 1-190.

[6] V. Dyakonov, Simulink 5/6/7: Samouchitel. Moskva: DMK-Press, 2009, pp. 1-784.

\section{Список використаних джерел}

[1] Афанасьев В.А. Руководство по технологии комбикормовой продукции с основами кормления животных. Воронеж: ОАО «Всероссийский научно-исследовательский институт комбикормовой промышленности», $2007.389 \mathrm{c}$.

[2] Хобин В.А, Бабиков А.Ю. Математическая модель рабочей зоны ситовой молотковой дробилки как объекта управления с изменяющимися свойствами. Наукові праці ОНАХТ. 2007. Вип. 30. Т. 2. С. 304 - 310.

[3] Хобин В.А, Бабиков А.Ю. Математическая имитационная модель молотковой дробилки как объекта управления в среде Simulink . Наукові пращ̧і ОНАХТ. 2006. Вип. 29. Т. 2. С. 236 - 240.

[4] Хобин В.А., Левинский М.В. Оптимизация фильтров собственного движения самонастраивающейся САУ объектом технологического типа. Радіоелектроніка, інформатика, управління. 2016. №4. С.120-129.

[5] Копелович, А. П. Инженерные методы расчёта при выборе автоматических регуляторов. Москва: Металлургиздат, 1960. 190 с.

[6] Дьяконов, В. Simulink 5/6/7: Самоучитель. Москва: ДМК-Пресс, 2009, 784 с. 